\title{
Evaluation of Virtual Biochemistry Practicum on First Year Students at Faculty of Medicine Universitas Islam Indonesia
}

\author{
Nur Aini Djunet ${ }^{1, *}$ Rizki Fajar Utami ${ }^{1,}$ Asri Hendrawati ${ }^{1}$ \\ ${ }^{1}$ Department of Biochemistry, Faculty of Medicine, Universitas Islam Indonesia \\ *Corresponding author. Email:187111307@ uii.ac.id
}

\begin{abstract}
The COVID-19 pandemic has forced all universities worldwide to adopt the virtual learning method as the new method of learning for students and lecturers, as applied in virtual practicum for Biochemistry. Virtual practicum is generally conducted for 110 minutes for each theme, starting with pre-test (10 minutes), introductory lectures (20 minutes), distribution of students to several breakout rooms (5 minutes), educational video playback accompanied by lecturer assistants in each BR (55 minutes), discussion with the lecturer (10 minutes), and post-test (10 minutes). On this basis, this research aims to evaluate virtual practicum methods on students' knowledge. The research was designed as a cross sectional study using a mixed-method approach. It engaged first-year students who took the first course and were eligible $(\mathrm{n}=177)$ as the research subjects. Subjects' identity was disguised by a code for ease of identification. Their knowledge levels were taken from pre-test and post-test scores, which were analyzed by Wilcoxon test. Qualitative data were obtained from observation of learning records and subject comments in the evaluation questionnaire. The thematic analysis revealed that about 159 students had a higher post-test score than pre-test. There was a different knowledge level ( $\mathrm{p}<0.0001)$ between before and after practicum. Their knowledge level before practicum was $70(30-90)$ and after that it increased to $87(50-100)$. Generally, the online practicum run smoothly. $32 \%$ subjects stated that they did not encounter any problems during the learning process, but a larger number of students complained about telecommunication signals (43\%), lack of practicum duration (17\%), preference on the offline system (7\%), and others $(1 \%)$. Hence, virtual learning using teaching videos can be used as an alternative learning method in biochemistry practicum.
\end{abstract}

Keywords: virtual practicum, teaching videos.

\section{INTRODUCTION}

The COVID-19 pandemic or coronavirus pandemic is an ongoing pandemic of coronavirus disease 2019 (COVID-19) caused by severe acute respiratory syndrome coronavirus 2 (SARS- CoV-2). On 30th January 2020, The World Health Organization (WHO) declared an outbreak of COVID-19 and announced its status as a pandemic in March 2020. [1] The virus spreads mainly in the air when people are physically near each other. This distant is known as "close contact", which was variously defined. The US Centres for Disease Control and Prevention (CDC) defined the "close contact" as the area within $\sim 1,8$ metres (six feets), and being face to face for a cumulative total of 15 minutes [2] or either 15 minutes of face to face proximity, while the Australian Health Department defined it as sharing a two hour session with the infected people. [3]
Indonesia reported the first case of COVID-19 on $2^{\text {nd }}$ March 2020 in Depok, West Java when three women who were a family living together in the same house were tested positive for the virus. The first three cases were followed by the significant raise of a number of new positively tested cases. To control and prevent the spread of COVID-19, the government declared some policies and health protocols, including the learning from home or school from home. In the middle of March 2020, Indonesian Ministry of Education and Culture (MOEC) announced school closures for all levels and enacted the start of the home or online learning program. Indonesian MOEC has prepared a support system to ensure the smooth operation of the program by building Androidbased virtual learning applications. However, these applications were only applicable for students and teachers of Early Childhood Education, Elementary Schools, Junior High Schools, Senior High Schools or Vocational Schools and equivalents. The government 
through MOEC and Ministry of Research, Technology, and Higher Education (MORTH) does not provide any virtual learning applications for higher education institutions.. Thus, the lecturers are required to develop their own online learning methods.

Faculty of Medicine Universitas Islam Indonesia (FMUII) has facilitated all lecturers to develop virtual learning methods during the pandemic. In its essence, virtual learning was not a new innovation in FMUII since a few courses in clinical skills training have frequently adopted its application. However, other courses were relatively unfamiliar with this type of learning. To support the learning outcome in the theoretical learning of biochemistry, we conducted some experiential or practicum methods. The first year students were provided with three courses of biochemistry practicum, one of which was Introductory Course. The Introductory Course contains three themes of biochemistry: carbohydrate, protein, and lipid. On this basis, we arranged three themes of practicum. Each theme of practicum lasts for 110 minutes. We used an educational video to demonstrate some biochemistry reactions, a novelty in biochemistry practice for us.

Knowing and knowledge have been two subjects of human inquiry from the ancient times. Knowing is one of the most specific human processes and knowledge is its results. Knowledge is one of the best sources of competitive advantage for everyone. It is a dynamic framework from which information may be stored, processed, and understood. It is considered as a dynamic human process of justifying personal belief towards the truth. [4] Adopted by an integrated view on the nature of knowledge, there are three kinds of knowledge: (a) experiential knowledge; (b) skills; and (c) knowledge claims. They are interconnected, but have some specific features of their own. [5] Knowledge is created through our sensory interface with the real world, and it is processed finally by our mind. As usual, we conducted offline practicum methods. It has been established for many years. Nonetheless, the pandemic changes everything around us. Thus, we arranged online practice as an alternative learning method and we need to know the effectiveness of this method. The purpose of this study was to evaluate online practicum methods on student knowledge.

\section{METHODS}

\subsection{Participants}

Subjects were all first-year students who took the first course. There were 194 subjects who were enrolled in this course, but only 177 subjects were eligible for our study. Ten subjects were repeaters, and seven subjects were excluded because they did not meet the inclusion criteria of the study. Then, the eligible subjects were given code to disguise their identity.

\subsection{Knowledge}

Student knowledge levels were measured based on their score on pretest and post-test. Their scores were analyzed by comparing the difference between the pretest and post-test. The difference in each theme of practicum were examined, and all themes were assessed.

\subsection{Teaching videos}

Teaching videos were prepared for three themes. We had 10 videos for carbohydrate themes, 10 videos for lipid themes, and six videos for protein themes. Every video consisted of three parts: introduction, main part, and closing. In the introduction we showed some reaction principles and materials required for the reactions. The videos on the main part demonstrated some reaction methods, and videos for closing highlighted the results and conclusions.

\subsection{Ethics}

The study protocol was approved by The Ethics Committee at Faculty of Medicine Universitas Islam Indonesia (No. 6/Ka.Kom.Et/70/KE/I/2021). All information of participants was kept confidential.

\subsection{Study design and protocol}

This research was a cross sectional study using a mixed-method approach. We used secondary data from three times of practicum. Carbohydrate theme was delivered on $9^{\text {th }}$ October 2020, lipid theme at $15^{\text {th }}$ October 2020 , and protein theme at $20^{\text {th }}$ October 2020. At the end of the course, we created a final test for those three themes on $27^{\text {th }}$ October 2020. A final test was designated to know the resistance of students' comprehension for those three themes. All sessions lasted from $1.00-2.50$ $\mathrm{pm}$. The whole 110 minutes of practicum time was divided for pretest, introductory lectures, students distribution to several breakout rooms, teaching video playback accompanied by lecturer assistants, discussion with the lecturer, and post-test. Lecturer assistants were the $4^{\text {th }}$ year students that had been briefed by the lecturer. Prior to class, they were required to watch and study all of the teaching videos that would be played. One lecturer assistant was tasked to accompany about 20 students in every breakout room. The lecturer joined all of the breakout room alternately, either through the laboratory technician or individually. Both of them supported the lecturer assistants in case there were some troubles. All of the teaching videos were run by lecturer assistants, but if problem occurred, the laboratory technician would help to solve it. The lecturer assistants' productivity were assessed by students. The students were asked to fill out the form on the assistant productivity. Hence, we analysed three different things: scores for each theme, a final test score, and lecturer assistants' productivity score 
as quantitative data. Then, we watched three records of all themes as qualitative data.

\subsection{Statistical analyses}

The results were reported as median (minimum maximum). Data were analysed using a Statistical analysis carried out using Wilcoxon test. Qualitative data were analysed thematically. helpful. Mean of assistant productivity scores was above 3,61, while the best score was 4,00. Many students had telecommunication signal problems. Surprisingly, the number of students who did not encounter any difficulties in the practicum went up gradually along the time. In the first practicum (carbohydrate theme), only seven students did not experience any difficulties, but in the last session (protein theme), the number skyrocketed to 55 students.

We assumed that there had been an increase of knowledge and comprehension of students as indicated

Table 1. Students' scores at three themes and their final test

\begin{tabular}{|l|c|c|}
\hline Variables & Median (minimum - maximum) & \\
\hline Carbohydrate Theme & & $\mathrm{p}=0,000^{\star}$ \\
\hline Pre-test & $60(10-90)$ & $21,6(\mathrm{Cl} 95 \% 19,1-24,2)^{\star}$ \\
\hline Post-test & $80(30-100)$ & \\
\hline Difference between pre and post-test & $20(20-70)$ & \\
\hline Lipid Theme & & $\mathrm{p}=0,000^{\star}$ \\
\hline Pre-test & $70(20-100)$ & $24,6(\mathrm{Cl} 95 \% 22,1-27,1)^{\star}$ \\
\hline Post-test & $90(60-100)$ & \\
\hline Difference between pre and post-test & $20(20-80)$ & $\mathrm{p}=0,017^{\star}$ \\
\hline Protein Theme & & $2,7(\mathrm{Cl} 95 \% 0,5-4,8)^{\star}$ \\
\hline Pre-test & $90(20-100)$ & \\
\hline Post-test & $90(50-100)$ & \\
\hline Difference between pre and post-test & $0(20-60)$ & \\
\hline & & \\
\hline Final test & $80(50-95)$ & \\
\hline
\end{tabular}

*Wilcoxon test

Table 2. Students' feedbacks

\begin{tabular}{|l|r|r|r|}
\hline Variables & Carbohydrate theme (\%) & Lipid theme (\%) & Protein theme (\%) \\
\hline Lack of practicum duration & 33 & 12 & 5 \\
\hline Telecommunication signal & 39 & 40 & 49 \\
\hline Unable to enjoy virtual practicum & 12 & 6 & 4 \\
\hline Adaptation & 6 & 0 & 0 \\
\hline No difficulty & 7 & 35 & 55 \\
\hline Others & 3 & 6 & 7 \\
\hline
\end{tabular}

\section{RESULTS}

Virtual biochemistry practicum using teaching videos could improve students' knowledge. Almost all of the students had higher post-test scores than pre-test. The post-test scores were 20 points higher in carbohydrate and lipid theme. Students had significant $(\mathrm{p}<0,000)$ score improvements at all themes. Qualitatively, the lecturer assistants could accompany students in the breakout room. Students considered the lecturer assistant was very by the improving median scores, and minimum scores in the post-tests. The improvement on the first theme was at the lowest, but it went up in the second and third themes. Data showed the final knowledge score was 80 (50 - 95). The final test consisted of carbohydrate, lipid, and protein themes. There were three weeks of lapse time from carbohydrate theme to final test, two weeks from lipid theme, and a week from protein theme. We uploaded all of the teaching videos in Panopto to allow all students to study it at all times. 


\section{DISCUSSION}

Knowledge is (1) an awareness or familiarity gained by experience of a person, fact, or things and a person's range of information; (2) a theoretical or practical understanding of a subject, language, etc and the sum of what is known; and (3) true, justified belief: certain understanding, as opposed to opinion. [6] In the past, we believe that knowledge can only be acquired through experience. Within an academic context of higher education institutions, if the empiricist view of knowledge was adopted, students could only claim to have acquired knowledge if and only the subjects they studied contained practical elements. In the COVID-19 pandemic situation, we could not practice this concept smoothly. Thus, we have to find another way to deliver knowledge to students.

Information refers to data which has developed and shaped to be of more meaning to users. It results from the interpretation of data in a provided background. Thus, a single material of data may create different information if the circumstance is different. Information refers to accumulation of processed data to allow comparison, grouping, and categorizing in order to be useful. Hence, information is organized data, tables, and statistical presentation in context. Data can be changed into information by accumulating order, context, and purpose. [7] We made teaching videos as organized data and transformed them to information by accumulating some learning outcomes. Knowledge is an organized information which could change something or somebody. [8] Students transformed information from teaching videos to knowledge by accumulating meanings and determining what they should do later. Knowledge is richer, deeper, and precious than information. It is derived from information, but it is more meaningful. It is important to solve the problem and make decisions, because it has stronger meaning than data and information. [9]

Virtual learning has had great relevance to support and promote formal education. Educational guidelines and curricula of formal education institutions in our country have implemented virtual learning. Virtual learning environment is a condition that relates teachers, students, and school in formal learning. The concept of virtual learning environment is a dynamic concept due to the constant evolution of digital technologies. [10] Some universities have used an educational system based on the web to complement their traditional face-to-face courses. These systems gather a great quantity of data which is valuable to analyse the course contents and students' use. [11] Learning environments based on the use of technology and digital resources are mediators of the learning process. They facilitate interaction and interrelation within a continuous communication process, then enhancing the construction and reconstruction of knowledge and meanings as well as the formation of habits and attitudes within a framework that is common to all the ones involved in the educational process. [12]
The COVID-19 pandemic has generated changes in the teaching-learning process and has influenced the interaction between lecturers and students. [13] Traditional education is more teacher-centered, but with the E-learning development, a shift towards a studentcentered education starts to emerge. [14] Differences between traditional and online learning may also be acknowledged in terms of principal sources information, assessment, or quality of education. In traditional education, students were evaluated only by lecturers. The quality of education depends on the lecturer's knowledge and skills. While in online learning, the evaluation may be done with the help of some tools and systems. Students can procure information from various documents uploaded on the platform, and the quality of education is influenced by the lecturers teaching style and the level of training that lecturers have in using technology. [15] Some principles that stand the core of effective online teaching are encouraging contact between students and faculty: collaborative learning, quick feedback, active learning, task time or students' encouragement to allocate more time for completing tasks; high expectations (lecturer should communicate their expectations in order to encourage and motivate students), diversivied learning, and technological application. [16] In line with this, Huang et al. identified some important aspects that have an essential role in optimizing learning in special circumstances as in the pandemic situation. These aspects are managing and developing internet infrastructure; using friendly tools; providing reliable, interactive, and diverse electronic resources; using social networks to build online communities for students; using various effective techniques such as learning based on discovery and experience; and providing services that help students and lecturers to learn about the latest policies adopted by universities. [17] Sun et al., in their study on students' experience during online learning showed that students believe lecturers should know how to adapt their lectures to the online environment, instead of simply transferring the information that was usually delivered in the traditional way to the online learning platform. Then, at the end, lecturers should give an adequate number of projects and assignments. [18] Given such condition, we assigned students to do some projects and assignments every time the virtual practice ended. Furthermore, we need to develop comparative studies on the results of offline and online learning that support its effectiveness in the educational field.

\section{CONCLUSIONS}

Virtual learning could be an alternative method to transfer knowledge. Lecturers, students, and institutions had to be well prepared for all of virtual learning needs. Lecturers must be innovative in creating some teaching aid tools and learning methods. Students had to prepare for the needs of virtual learning themselves, and the most important was to manage and develop internet infrastructure in order to avoid interruptions. 


\section{AUTHORS' CONTRIBUTIONS}

Conceptualization and project administration, N.A.D.; methodology, N.A.D., R.F.U.; software, N.A.D.; investigation N.A.D.; resources, A.H.; writing-original draft preparation, N.A.D.; writing-review and editing, N.A.D., R.F.U., A.H. All authors have read and agreed to the published version of the manuscript.

\section{ACKNOWLEDGMENTS}

The authors would like to thank the laboratory technicians and students for their valued contribution during the research process.

\section{REFERENCES}

[1] C. Sohrabi, Z. Alsafi, N. O'Neill, M. Khan, A. Kerwan, A. Al-Jabir, \& et al, World Health Organization declares global emergency: A review of the 2019 novel coronavirus (COVID-19), vol. 76, Int J Surg, 2020, pp. 71-76. DOI: https://doi.org/10.1016/j.ijsu.2020.02.034

[2] CDC, Covid-19, Centers for Disease and Prevention, 2020, October 21, http://www.cdc.gov

[3] Australian DOHA, Quarantine for coronavirus (COVID-19), Departmen of Health Australian Government, 2021, February 25, http://www.health.gov.au

[4] H. Mohajan, Knowledge is an essential element at present world, vol. 1(1), IJPSS, 2016, pp. 31-53. https://mpra.ub.uni-muenchen.de/83041/

[5] E. Dombrowski, L. Rotenberg, M. Bick, Theory of knowledge, Oxford Press University, 2013.

[6] D. Thomson, The Concise Oxford Dictionary 9th Ed, Oxford University Press, 1998, pp.753.

[7] X. Cong, K. Pandya, Issues of knowledge mangement in the public sector, vol. 1(2), Electron. J. Knowl. Manag, 2005, pp. 25-33.

[8] J. Gajda, The role of thrust in knowledge management organization, vol. 5(1), J. Interdiscip. Multidiscip. Res, 2015, pp. 19-21.

[9] G. Servin, C. De Brun, ABC of knowledge management. NHS National Library for Health: Knowledge Management Specialist Library, 2005, http://www.library.nhs.uk

[10] P. Alves, L. Miranda, C. Morais, The influence of virtual learning environments in students' performance, vol. 5(3), Univers. J. Educ. Res, 2017, pp. 517-527. DOI: 10.13189/ujer.2017.050325

[11] S. Valsamidisa, I. Kazanidisa, I. Petasakisa, S. Kontogiannisb, E. Kolokithaa, E-learning activity analysis, vol. 9, Procedia Econ, 2014, pp. 511-518.
[12] E. Becerra, M. Garcia, R. Chavez, Ambiente de aprendizaje con uso de tecnologia en la formacion docente inicial y las habilidades intelectuales, In R. Navarro, M. Pacheco, Y. Rangel, M. Montoya, Foro interregional de investigacion sobre entornos virtuales de aprendizaje, Redtic, 2011, pp. 154-164.

[13] A. Sobaih, A. Hasanein, A. Abu Elnasr, Responses to COVID-19 in higher education: social media usage for sustaining formal academic communication in developing countries, vol. 12, Sustainability, 2020, 6520 .

[14] K. Gallie, D. Joubert, Paradigm Shift: From traditional to online education, vol. 1, Stud. Learn. Eval. Innov. Dev. SLEID, 2004, pp. 32-36.

[15] M. Nycz, E. Cohen, The basics for understanding elearning. In N. Buzzetto-More, Principles of effective online teaching, Informing Science Press, 2007, pp. 1-17.

[16] C. Cheung, J. Cable, Eight principles of effective online teaching: a decade-long lessons learned in project management education, vol. 6, Proj. Manag. World J, 2017, pp. 1-16.

[17] R. Huang, A. Tlili, J. Yang, T. Chang, H. Wang, R. Zhuang, et al, Handbook on Facilitating Flexible Learning During Educational Disruption: The Chinese Experience inMaintaining Undisrupted Learning in COVID-19 Outbreak, Smart Learning Institute of Beijing Normal University, 2020.

[18] L. Sun, Y. Tang, W. Zuo, Coronavirus pushes education online, vol. 19, Nat. Mater, 2020, pp. 687. 